
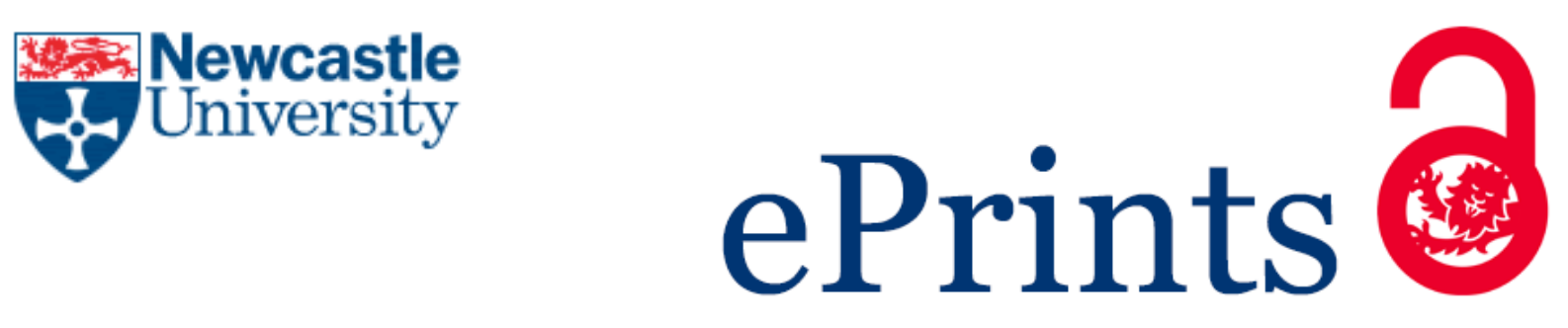

Patten Keith. Law, workplace bullying and moral urgency. Industrial Law Journal 2017.

DOI: https://doi.org/10.1093/indlaw/dwx017

\title{
Copyright:
}

This is a pre-copyedited, author-produced PDF of an article accepted for publication in Industrial Law Journal following peer review. The version of record Patten Keith. Law, workplace bullying and moral urgency. Industrial Law Journal 2017 is available online at:

https://doi.org/10.1093/indlaw/dwx017

DOI link to article:

https://doi.org/10.1093/indlaw/dwx017

Date deposited:

03/07/2017

Embargo release date:

23 August 2019

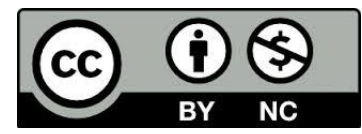

This work is licensed under a Creative Commons Attribution-NonCommercial 3.0 Unported License 


\section{Law, workplace bullying and moral urgency}

Keith Patten, lecturer, Newcastle Law School, Newcastle University, NE1 7RU, 0191 208 5569, keith.patten@ncl.ac.uk

The law's approach to workplace bullying is fragmented and unsatisfactory. Where bullying is carried out for a discriminatory reason there is a specific cause of action in the Equality Act, although this, itself, has significant limitations. If the bullying is for a non-discriminatory reason not even this level of targeted protection is available. This article discusses the phenomenon of workplace bullying and argues that a free-standing cause of action is required to provide some measure of legal protection to victims.

\section{$\underline{\text { Introduction }}$}

This article considers the issue of workplace bullying and the law's response to it. It will begin by briefly considering the prevalence and effects of bullying at work, in order to demonstrate the scale and importance of the problem. It will then look at current avenues of legal redress and assess the extent to which those are effective in providing fair and adequate protection to victims. It will seek to argue that too many bullying victims are currently let down by the law, which provides inadequate and piecemeal protection. Finally, it will look at some possible ways forward and, in particular, evaluate a recent piece of legislative reform in a common law jurisdiction, the Employment (Bullying at Work) Act 2014 in Gibraltar. This legislation seeks to 
remedy some of the deficiencies which are found in UK law. The article will conclude that while this legislative approach does represent a step forward, it also has deficiencies of its own which may limit its effectiveness.

\section{The phenomenon of workplace bullying}

Being opposed to bullying in the workplace could be regarded as a 'virtue' concept ${ }^{1}$. There is no pro-bullying lobby². There are, however, significant differences as to what constitutes bullying. While perpetrators do not tend to self-identify as bullies, they (and others) may often excuse their behaviour under various labels which may include 'effective' management, banter or mere personality clash ${ }^{3}$. Victims may find themselves labelled as overly sensitive, precious or unable to take a joke. For Furedi, for example 'experts have redefined elementary forms of unpleasant and insensitive behaviour as bullying ${ }^{4}$. He goes on to classify most things 'branded as bullying' as being 'what used to be called workplace politics ${ }^{5}$ '. It is clear, therefore, that any assessment of the problem runs quickly into issues of definition. What do we mean by workplace bullying?

These definitional issues are contested ground. As Randall puts it, 'Agreed definitions of bullying do not exist ${ }^{6}$. But while a precise and universal definition may be hard to come by there are some common themes around which researchers (or at least sociological researchers) coalesce. Empirical research into workplace bullying is of surprisingly recent origin, beginning in Scandinavia in the 1980s and it

\footnotetext{
${ }^{1}$ In an Aristotelian sense - Aristotle, The Nicomachean Ethics, David Ross and Lesley Brown (eds) (Oxford: Oxford University Press, 2009) 20

${ }^{2}$ Angela Ishmael - Harassment, bullying and violence at work (London: The Industrial Society, 1999) xi - xii

${ }^{3}$ Andrea Adams - Bullying at Work. How to confront it and overcome it (London: Virago Press, 1996) 87 - 95

${ }^{4}$ Frank Furedi - Entrenched in a culture of workplace politics, or could it be you're picking on me again? The Australian (Surrey Hills, New South Wales, $6^{\text {th }}$ July 2012).

${ }^{5}$ Ibid

${ }^{6}$ Peter Randall - Adult Bullying - Perpetrators and Victims (London: Routledge, 1997) 3
} 
is from here that definitions have emerged. Einarsen et al consider that 'Bullying at work means harassing, offending or socially excluding someone or negatively affecting someone's work ${ }^{7}$. This or other similar definitions have tended to inform much (but not all) of the sociological research on the prevalence of bullying. This does not mean that a definition along these lines would necessarily be sufficient for the purposes of the law. Sociology is about identifying and explaining social phenomena. Law is about the allocation of rights enforceable in an adjudicative process. These different aims may require a different approach. I will return later to how we might seek to define bullying in a legal sense, but for the present it is sufficient to observe that, for example, the sociological definition lacks any consideration of the perspective from which the question is being asked. To put that in a way lawyers might do, the extent to which the test is subjective or objective is left open.

The difficulty of measuring the extent of the problem may have a second element. The extent of bullying may be resistant to accurate measurement because of a reluctance on the part of victims to identify themselves as such ${ }^{8}$. These two problems combined (lack of precise and agreed definitions across different research projects and a reluctance of victims to self-identify) may help to explain the wide variations produced in research on prevalence. Beswick et al, in an extensive review of the research evidence, noted prevalence rates ranging from about $2 \%$ up to some $25 \%$. The higher figures tended to be in response to somewhat bland questions of

\footnotetext{
7 Stale Einarsen, Helge Hoel, Dieter Zapf, Cary L Cooper - 'The Concept of Bullying and Harassment at Work: the European Tradition' in Stale Einarsen, Helge Hoel, Dieter Zapf, Cary L Cooper (eds) Bullying and Harassment in the Workplace ( $2^{\text {nd }}$ edn, Boca Raton: CRC Press, 2011) 22.

${ }^{8}$ Ishmael, supra, n2 106 - 112; David Wornham, 'A descriptive Investigation of Morality and Victimisation at Work' (2003) $45 \mathrm{~J}$ of Bus Ethics 30; Therese O'Donnell. 'The Sweat of the Brow or the Breaking of the Heart' in Anne Morris and Therese O'Donnell (eds), Feminist Perspectives on Employment Law (London: Cavendish Publishing, 1999) 74-75.
} 
the 'have you been bullied?' type, whereas the lower figures tended to be produced using the somewhat more focused types of definition referred to above ${ }^{9}$. Based on a UK workforce in the order of $31,400,000^{10}$, even the lower figure amounts to over 600,000 people. Bearing in mind that the HSE estimates that some 611,000 suffered a non-fatal injury at work during $2014 / 15^{11}$ the prevalence of workplace bullying seems likely to be not much less than the prevalence of occupational injury, and may be considerably greater.

Bullying is, of course, a very diverse phenomenon and it is not, therefore, surprising that its effects can also be varied. But, despite that, there is ample evidence that bullying can cause significantly adverse consequences. Problems arise most obviously for the victims, who may suffer ill-health, loss of self-esteem, absence from work and all the consequent effects of those things, personal, professional and financial $^{12}$. Interestingly, there is evidence to suggest that some, at least, of these consequences are present in those who merely witness bullying in the workplace, even when they, themselves, are not victims ${ }^{13}$. Indeed, bullying may be a problem not merely for the victims (or witnesses). It may also be an organisational problem for the employer. There is evidence that bullying within a workplace can cause absenteeism, loss of productivity and a generally poorly cohesive work

\footnotetext{
${ }^{9}$ Johanna Beswick, Joanne Gore, David Palferman, Bullying at Work: a review of the literature (London: Health \& Safety Laboratory, 2004)

${ }^{10}$ Office for National Statistics, UK Labour Market, March 2016, https://www.ons.gov.uk/employmentandlabourmarket/peopleinwork/employmentandemployeetypes/bulleti ns/uklabourmarket/march2016\#summary-of-latest-labour-market-statistics, accessed 30 ${ }^{\text {th }}$ March 2016

${ }^{11}$ http://www.hse.gov.uk/Statistics/causinj/index.htm , accessed 30 ${ }^{\text {th }}$ March 2016

12 Helge Hoel and Cary L Cooper, Destructive conflict and bullying at work (Manchester: British Occupational Health and Research Foundation, 2000) $21-26$.

13 lbid $20-21$
} 
environment which is likely to be damaging in terms of the ability of the organisation to achieve its goals more effectively ${ }^{14}$.

Notwithstanding measurement difficulties, producing problems as to whether or not what is being counted is always a sufficiently uniform phenomenon, there does seem to be ample evidence from the field of occupational sociology to establish the fact that workplace bullying is a real and present social issue. Indeed, there is a further important aspect of such conduct in a workplace context. This is the relative inability of the victim to walk away. Work, by its nature, provides an enclosed arena. Someone exposed to similar conduct in a more casual or social setting may, frequently, be free to choose to disassociate themselves from the context. Such an option is not readily available to someone at work, where the victim will often be trapped by economic pressures. Work is an environment where the individual's autonomy already suffers a degree of inevitable constraint. In addition, of course, many people are likely to spend a significantly greater proportion of their time with work colleagues than they do with social acquaintances. On top of all this is the way in which many people regard work in modern times. Very often this is not seen as merely an economic transaction. As Lord Hoffmann has remarked, 'It has been recognised that a person's employment is usually one of the most important things in his or her life. It gives not only a livelihood but an occupation, an identity and a sense of self-esteem ${ }^{15}$.' Taken together, these three features of the workplace (the inability to walk away, the sheer amount of a person's life work may occupy and the increasingly dignitarian perceptions of work) help explain why work may require

\footnotetext{
${ }^{14}$ Ibid $25-26$

15 Johnson v Unisys Ltd [2001] UKHL 13; [2003] 1 AC 518 [35]
} 
solutions that are distinct from any solutions that may be required in other social contexts.

The three factors referred to above (the prevalence of workplace bullying on even the more conservative assessments, the adverse impact which bullying has, most particularly on the victims, and the special nature of the workplace) indicate why this is a problem of some degree of moral urgency. Significant numbers of people are suffering real distress (if not, indeed, harm) in circumstances from which they cannot easily escape. This would seem to establish a problem of sufficient importance to merit some response. Law, it is submitted, has a duty to assist these people, in so far as it can do so consistently with achieving other aims.

\section{The law's current approach to workplace bullying}

So, as the law currently stands, what can a worker who is a victim of workplace bullying, do about it?

It is clear that the law does, currently, have some responses to workplace bullying. Indeed, it may be fair to say that the law categorises victims of such bullying in 2 ways. The first group are those bullied on account of their race, sex, religious faith etc (an equality related reason within the terms of the Equality Act 2010). The second relates to those bullied at work for some other reason or, indeed, for no discernible reason at all. In one sense it might be legitimate to describe the former group as the 'protected' bullied in that the law seeks to make specific provision for them. This provision is, however, far from perfect and it may turn out to be the case that the advantages of this group are, to a degree, no more than symbolic.

The rights of the so-called protected group are found in section 26 of the Equality Act 2016 . This requires the bullying to be related to one of the protected 
characteristics within the Act. These include what might be termed the 'traditional' protections based upon race and sex, and the 'newer', and extended protections which include sexual orientation, gender reassignment, age and religion and belief ${ }^{16}$. In this context the cause of action created is called 'harassment', rather than bullying. This raises the issue of whether or not there is a meaningful distinction between the conduct required to constitute the two phenomena. It is submitted here that there is no distinction of substance between these. That, at least, appears to be the position in the literature of occupational sociology which has driven the empirical research in this area where the terms bullying and harassment are used more or less interchangeably ${ }^{17}$. In the UK the term 'harassment' became associated with bullying when it was discrimination related. Consequently there may be a distinction between the two terms in so far as they concern the motivation of the perpetrator, but not in so far as they concern the nature of the conduct and, therefore, its likely effects. This seems to be acknowledged in a legal context by Hepple, who has tentatively suggested removing the cause of action from the restriction imposed on it by requiring it to be causally related to a protected characteristic, while retaining the conduct element unchanged ${ }^{18}$.

By section 26(1) a person commits harassment if he engages in 'unwanted conduct related to a relevant protected characteristic' and the conduct in question

\footnotetext{
${ }^{16}$ Equality Act 2010, s 4

${ }^{17}$ Dieter Zapf and Stale Einarsen, 'Mobbing at Work: Escalated Conflicts in Organisations' in Suzy Fox and Paul E Spector (eds), Counterproductive Work Behaviour: Investigations of Actors and Target (Washington DC: American Psychological Association, 2005) 237 - 245. The term 'mobbing' is often used as an alternative to the term 'bullying' in non-English speaking countries.

${ }^{18}$ Bob Hepple, 'Freedom of Expression and the Prohibition of Harassment' in Jack Beatson and Yvonne Cripps (eds) Freedom of Expression and Freedom of Information. Essays in Honour of Sir David Williams (Oxford: Oxford University Press, 2000) 196 - he describes the idea as '...a matter for consideration...'. The same argument is also floated by Hepple at around the same time in Bob Hepple, Mary Coussey and Tufyal Choudhury, Equality,: A New Framework (Oxford: Hart, 2000). A similar solution is also raised by O'Donnell, supra, n8 85, an equally long time ago
} 
'has the purpose or effect' of either violating the dignity of the victim or 'creating an intimidating, hostile, degrading, humiliating or offensive environment' for the victim. The question is to be determined according to a mixed subjective/objective test, with both the perception of the victim and whether it was reasonable for the conduct to have the adverse effect being relevant considerations ${ }^{19}$.

The scope for section 26 to provide an effective remedy against workplace bullying is limited by two factors. The first is its requirement of a causal link to a protected characteristic. This means that someone bullied because of their ethnic origin may be able to pursue a claim, whereas someone subjected to similar conduct because of the colour of their hair will not. The second limitation is the threshold at which the tribunals have sought to set the sanctioned conduct required to constitute a cause of action. In the Employment Appeal Tribunal decision of Betsi Cadwaladr University Health Board $v$ Hughes, Langstaff $\mathrm{P}$ emphasised that the qualifiers in the section ('violating dignity', 'intimidating', 'hostile' etc.) are strong words and that 'all look for effects which are serious and marked ${ }^{20}$.' This echoes similar comments made by Elias LJ in Land Registry $v$ Grant when he emphasised in relation to those qualifiers that 'Tribunals must not cheapen the significance of these words. They are an important control to prevent trivial acts causing minor upsets being caught by the concept of harassment ${ }^{21}$.' While accepting that the tribunals need to exercise care not to turn section 26 into a provision overly burdensome on employers the stress placed on the magnitude of the hurdle facing employees pursuing claims under

\footnotetext{
${ }^{19}$ Equality Act 2010 s 26(4). S 26(2) and s 26(3) also create separate but related causes of action, respectively, where the conduct is of a sexual nature, or where it relates to the victim's submission or rejection of sexual advances. Both of those work in substantially the same way as does the cause of action in s 26(1). ${ }^{20}$ (2014) Appeal No. UKEAT/0179/13/JOJ [10]-[12].

21 [2011] EWCA Civ 769; [2011] ICR 1390 [47] (CA). See also General Municipal and Boilermakers Union v Henderson [2015] IRLR 451 (EAT).
} 
section 26 does have the potential to limit its effectiveness. When combined with the fact that it provides no protection at all to those bullied for reasons not linked to a protected characteristic section 26 may, at least in its present form, fall short as a tool to tackle workplace bullying.

While section 26 offers some limited but targeted assistance to those able to link their treatment to one of the protected characteristics, those who are bullied for other reasons are in an even more precarious position. Such people have no purpose built cause of action along the lines of section 26. Instead they are left with trying to fit their situation into other causes of action not designed for the purpose.

The options available to this group are largely threefold - a claim in common law negligence, a claim under 'ordinary' employment law, and a claim under the Protection from Harassment Act 1997. It will be necessary to look briefly at each in order to outline why it does not provide a suitable remedy.

The first of these is a claim founded in common law negligence. Although put in this way, such a claim could equally be based in contract on the implied term to take reasonable care for the health and welfare of an employee (or, indeed, the implied term of mutual trust and confidence $)^{22}$. The content of the duty is, it is submitted, the same irrespective of which approach is adopted ${ }^{23}$. That such a claim in neglgence might encompass the circumstances of workplace bullying is made clear by the House of Lords in Waters $v$ Commissioner of Police for the Metropolis ${ }^{24}$. Perhaps the first point to be made about this case is that it proceeded to the House of Lords on a preliminary issue, the defendant's application to strike out the claim as

\footnotetext{
${ }^{22}$ Gogay v Hertfordshire County Council [2000] IRLR 703

${ }^{23}$ The Honourable Mr Justice Langstaff, 'The Employer's Duty of Care' in Daniel Bennett (ed), Munkman on Employers' Liability (16 ${ }^{\text {th }}$ edn, London: LexisNexis, 2013) 117-118

24 [2000] 1 WLR 1607
} 
disclosing no cause of action, and so it says little about the precise circumstances required to give rise to a claim. The claimant, a female police officer, had made allegations of a sexual assault against a fellow, male, officer. As a result of making those allegations she alleged she had been subject to a campaign of bullying by colleagues which the defendant had either failed to prevent or control, or for which it was vicariously liable. As Lord Slynn put it - 'At the heart of her claim lies the belief that the other officers reviled her and failed to take care of her because she had broken the team rules by complaining of sexual acts by a fellow police officer'25.

The House of Lords declined to strike out the claim, but in doing so identified the two key (and related) problems standing in the way of a bullied claimant seeking to make out a claim in negligence. As Lord Slynn again put it -'If an employer knows that acts being done by employees during their employment may cause physical or mental harm to a particular fellow employee and he does nothing to supervise or prevent such acts, when it is in his power to do so, it is clearly arguable that he may be in breach of his duty to that employee'26.

From this can be extracted the two problems facing a claimant pursuing such a common law claim, firstly, that she must prove that she has suffered a recognised psychiatric injury and, secondly, that injury must have been reasonably foreseeable. The requirement to prove a psychiatric injury is a remnant of the long standing historical antipathy of the common law to non-physical injury ${ }^{27}$. It can be seen as an application of the de minimis principle, but an application of that principle which sets the threshold higher than that for physical harm. This is not the place to critique the

\footnotetext{
25 Ibid 1610

26 ibid 1611

${ }^{27}$ Hinz v Berry [1970] 2 QB 40, 42 (Lord Denning MR)
} 
common law's stance in requiring such injury to be proved. Rather the purpose is to indicate why this creates a problem for the bullied worker. It can be taken as a reasonable assumption that those who are bullied at work do not wish to be made psychiatrically ill28. This assumption may be extended to suggest that what most people in such a position want is for the bullying to stop before they come anywhere near to reaching that stage. But the action in common law negligence is simply not interested in claimants who have not become sufficiently badly effected as to be labelled by a psychiatric diagnosis. As such, common law negligence operates at too late a stage to be helpful in solving the underlying problem.

Not merely does the claimant need to prove the existence of a psychiatric injury she must also prove that such injury was reasonably foreseeable to her employer. The requirement stems from the general law of negligence in relation to psychiatric harm summed up by Hale LJ in her 16 propositions in Hatton $v$ Sutherland ${ }^{29}$. Despite protestations to the contrary (that no special control devices apply to such case ${ }^{30}$ ) Hale LJ's proposition 7 would suggest, at least, that the operation of foreseeability in psychiatric injury cases presents a particularly troublesome hurdle. As that proposition puts it, 'To trigger a duty to take steps, the indications of impending harm to health arising from stress at work must be plain enough for any reasonable employer to realise that he should do something about it'31. This might legitimately be termed 'extremely clear-cut' foreseeability. The

\footnotetext{
${ }^{28}$ It is clear that bullying can have adverse health consequences that would nevertheless fall short of a recognised psychiatric illness and which would not, therefore, be actionable at common law for that reasonGina Vega and Debra R Comer, ' Sticks and Stones may Break Your Bones, but Words can Break Your Spirit: Bullying in the Workplace' (2005) 58 Journal of Business Ethics $101-109$

${ }^{29}$ [2002] EWCA Civ 76; [2002] ICR 613

30 ibid, [22]

31 ibid, [43]
} 
application of this in a bullying type case is illustrated by Banks $v$ Ablex $L t d^{32}$, where the claimant alleged she had been the victim of a fellow employee whose conduct was aggressive and abusive. The Court of Appeal rejected her common law claim on the basis that the employer did not know or have any reason to know that she was at risk of imminent psychiatric injury. Such an approach places a heavy burden on the victim themselves to be proactive in reporting problems at an early stage. But there may be many reasons why such a victim is unlikely to do that, for example the reluctance to appear weak, or the concern that reporting problems may be likely to make the bullying worse. Indeed, this last point suggests that it is those employers in whom workers have the least confidence of effective action in response to a complaint who may effectively inoculate themselves from ever receiving complaints in the first place. This matter is not remedied by looking at the problem as one of vicarious liability for the conduct of the bully. Vicarious liability attaches to the torts committed by employees, not merely to their actions ${ }^{33}$, so unless the bully themselves foresaw (or should reasonably have foreseen) a risk of psychiatric injury then there will be no tort in the first place to which vicarious liability can attach itself. Leaving aside the obvious evidential issues that may present, if a victim is unwilling to complain to her employer it is not hard to imagine she will be even more reluctant to make the bully himself aware of how his conduct is affecting her.

If the common law of negligence does not provide an obvious solution for the bullied worker then what I have categorised as 'ordinary' employment law also presents one significant hurdle. Like the requirement of a psychiatric injury in

\footnotetext{
32 [2005] EWCA Civ 173; [2005] ICR 819

33 The Honourable Mr Justice Langstaff, 'Psychiatric Injury, Stress and Harassment' in Daniel Bennett (ed), Munkman on Employers' Liability (16 ${ }^{\text {th }}$ edn, London: LexisNexis, 2013) 444. See also Majrowski $v$ Guys and St Thomas's NHS Trust [2006] UKHL 34; [2007] 1 AC 224
} 
negligence cases this can be seen as an outcome related problem. The cornerstone of employment law is unfair dismissal ${ }^{34}$. Employment law has, for the most part, relatively little to offer the employee who has not been dismissed. So, for these purposes 'ordinary' employment law means the law of unfair dismissal and, as the name would suggest, that may also require the victim to end up in a place he may well not want to be, in this case dismissed. Ending up without a job probably does not represent the outcome the employee is seeking to achieve. Securing a situation where the bullying stops and the victim is able to get on with things is not an outcome offered by 'ordinary' employment law remedies ${ }^{35}$. Just as with negligence, but for different reasons, unfair dismissal protection operates at the wrong point in the timeline.

The Protection from Harassment Act 1997 might, on the face of it, have seemed to offer the best route to redress for the bullied worker. In order to see why this seems not to have been the case it will be necessary to look a little at both the structure of the Act and its origins. By section 1 the Act prohibits a course of conduct, which amounts to harassment and which the defendant knows or ought to know amounts to harassment. The requirement of a course of conduct is clarified by section 7(3) as being 'conduct on at least two occasions'. While it is clear that the definition of the cause of action includes an objective element, the type of conduct which constitutes harassment is not defined by the Act. The closest we get is again found in section 7 where we discover that 'conduct' includes 'speech' and that

\footnotetext{
${ }^{34}$ Described as the 'tail [wagging] the whole dog of the employment relation' - Hugh Collins, Justice in Dismissal (Oxford: Oxford University Press, 1992) 270

${ }^{35}$ Although under ss $112-116$ Employment Rights Act 1996 the primary remedy for unfair dismissal is reinstatement or reengagement, the reality is that the overwhelming remedy awarded in practice is compensation.
} 
harassing someone includes 'alarming the person or causing the person distress'. By section 3 victims are given a civil remedy enforceable as a statutory tort.

From the point of view of the person bullied in the workplace this Act may have several clear advantages which stake it out from a claim in common law negligence. The two key difficulties in pursuing a claim in negligence for workplace bullying (the requirement of having suffered a recognised psychiatric illness and the requirement that such injury should have been reasonably foreseeable) are both avoided. The first is made explicit by section 3(2) which confirms that 'damages may be awarded for (among other things) any anxiety caused by the harassment' (thereby setting the threshold of harm at a much lower level). That there is also no requirement of reasonable foreseeability flows from the wording of the statute itself but was made explicitly clear by the Court of Appeal in Jones $v$ Ruth ${ }^{36}$ where Patten LJ observed 'I am not persuaded that foreseeability of the injury or loss sustained by a claimant in a case of harassment is an essential element in the cause of action'37, and certainly there appeared to be nothing in the evidence in that case (which was successful) that would seem to have established foreseeability. In passing, we might observe that a claim under the Act has a third advantage over a claim in common law negligence, which is that it has a limitation period of 6 years as opposed to $3^{38}$. The Act has the obvious advantage over a claim in 'ordinary' employment law in that the claimant does not need to have lost his job.

As the majority of workplace bullying is, by its very nature, likely to satisfy the requirement of being a course of conduct, in the sense that its very repetition is an

\footnotetext{
36 [2011] EWCA Civ 804; [2012] 1 WLR 1495

37 ibid, [32]

${ }^{38} \mathrm{~S} 6$, although this period is not subject to any discretionary extension under s 33 Limitation Act 1980
} 
essential element of the problem ${ }^{39}$, the effectiveness of the Act in this context would seem to rest on the approach of the courts to the type of conduct which will be regarded as constituting harassment. For those who would seek to use the Act for the protection of the bullied worker this has proved to be a disappointment. The source of that disappointment lies, it is submitted, in two distinct but related facets of the Act. The first of those is its original aims as set out in the Parliamentary debates which led to its enactment. There is no disguising the fact that workplace bullying was not the mischief at which the Act was aimed. The debates centred largely on the problems of stalking (whether or not the Act was particularly successful in those terms is another matter) and, to a lesser degree on the issue of 'neighbours from hell'. The possibility that this Act would have anything at all to do with workplace bullying was not debated ${ }^{40}$. Indeed, until the House of Lords confirmed that the Act did give rise to vicarious liability its usefulness in workplace cases appeared limited ${ }^{41}$. But even in the act of confirming that an employer could be vicariously liable for workplace harassment under the Act the House of Lords was at pains to limit the Act's effectiveness in that very field. The reason for this, it is submitted, is a second feature of the Act, based not so much in its origins but in its structure. This is that by virtue of section 2 of the Act harassment is also made into a criminal offence. There is no difference in the definition of the nature of the conduct which constitutes harassment as crime or as tort, leading to the conclusion that the same conduct

\footnotetext{
${ }^{39}$ Stale Einarsen, Helge Hoel, Dieter Zapf, Cary L Cooper, 'The Concept of Bullying and Harassment at Work: the European Tradition' in Stale Einarsen, Helge Hoel, Dieter Zapf, Cary L Cooper (eds), Bullying and Harassment in the Workplace ( $2^{\text {nd }}$ edn, Boca Raton: CRC Press, 2011)
}

\footnotetext{
40 HC Deb 17th December 1996, cols 781-820; HL Deb 24 th January 1997 cols 917 - 943

${ }^{41}$ Majrowski v Guys \& St Thomas's NHS Trust [2006] UKHL 34; [2007] 1 AC 224
} 
which can give rise to a civil remedy must also be capable of giving rise to a criminal sanction, the only difference in the two lying in the burden of proof. It is this linkage of the civil action with a crime that seems to have led to the courts placing the threshold level of conduct required to constitute harassment at a high level. Thus, in Majrowski itself Lord Nichols makes a distinction between conduct '... which is unattractive, even unreasonable, and conduct which is oppressive and unacceptable. ${ }^{42}$ It is only at the level of 'oppressive and unacceptable' conduct that a cause of action will be made out. He expressly linked the level of conduct required with the criminal offence under section 2 and effectively excluded from the cause of action 'irritations, annoyances, even a measure of upset...' which arise in the day to day dealings that people have with each other ${ }^{43}$.

In Majrowski the allegations were that a supervisor had been rude and abusive to the claimant, had set him unachievable targets, and had refused to speak to him $^{44}$. On the basis of the Einarsen definition mentioned earlier this kind of conduct would, on the face of it, seem to fall squarely within the ambit of workplace bullying. It would, at the very least, seem to be an example of socially excluding someone. But despite having pursued the more technical issue of vicarious liability (successfully) all the way to the House of Lords the action appears subsequently to have been discontinued, seemingly because the claimant (or his advisors) did not believe they would surmount the liability obstacles set up in the obiter comments of Lord Nichols ${ }^{45}$.

\footnotetext{
42 ibid [30]

43 ibid

44 ibid [2]

${ }^{45}$ David Woods, It's hard to deal with harassment when legal definitions of it conflict HR Magazine, $26^{\text {th }}$ January 2010
} 
The manner in which this threshold level of conduct might be applied by the courts is illustrated in Conn $v$ The Council of the City of Sunderland ${ }^{46}$. Mr Conn was a paver for the Council. He alleged a course of conduct against his supervisor which amounted to harassment and which consisted of 5 separate incidents. In the end the Recorder found only two of those incidents to be proved as alleged, but that was still sufficient to constitute a course of conduct and he found the defendants liable for the harassment of Mr Conn. This decision was overturned in the Court of Appeal. The two incidents which had been found to be proved consisted, firstly, of an aggressive shouting at Mr Conn by the supervisor when Mr Conn declined to 'shop' workmates who were leaving site early. The incident took place in a cabin and the supervisor lost his temper to the degree that he threatened to 'punch out the windows of the cabin'47. The second incident was a direct threat of violence against Mr Conn in the course of a disagreement. Gage LJ, giving the leading judgment of the court, regarded the first incident as not even being close to the threshold level of conduct required to constitute harassment. Rather this was 'the sort of bad tempered conduct which, although unpleasant, comes well below the line of that which justifies a criminal sanction'48. Even in relation to the second incident which, let us not forget, was a threat of violence, Gage LJ regarded it as 'not free from doubt' that that met the threshold level of harassment ${ }^{49}$. In the event as that final incident was the only one left there was no possibility of the claimant satisfying the requirement of a course of conduct and, consequently, the matter did not need to be decided.

\footnotetext{
${ }^{46}$ [2007] EWCA Civ 1492 [2008] IRLR 324

47 ibid [5] - on any basis this is a somewhat odd threat, but, perhaps, indicates a supervisor who has lost control of his temper to a significant degree

48 ibid [15]

49 ibid
} 
The purpose of this article is not a detailed consideration of the Protection from Harassment Act and the cases that have arisen under it. The issue is whether it presents a workable option for the bullied worker to seek redress, and the high threshold of conduct required to satisfy the test of harassment suggests that it does not. The level at which this conduct is set seems to be much to do with the linkage of the civil remedy with the criminal sanction, a factor emphasised many times by the courts $^{50}$. Indeed, it is perfectly possible to feel some sympathy for Mr Conn, who is left without a remedy, while at the same time fully understanding the concerns of Gage LJ. This may well not be the kind of conduct which justifies a criminal sanction. That does not mean it ought not to merit a civil remedy and the fact that the second encompasses the first is really the problem facing the Act in being a realistic option for the bullied worker.

The conclusion we would seem to reach is that existing legal remedies to the problem of workplace bullying all appear to be ineffective in key ways. Section 26 is limited by the reluctance of the courts and tribunals to give an expansive interpretation to its qualifying adjectives, as well as by its structural position as a part of discrimination law, negligence is limited by the requirements of both recognised psychiatric injury and the need that such injury be reasonably foreseeable, unfair dismissal is limited by the jurisdictional need to have lost the job, and the Protection from Harassment Act is limited by the high threshold level of conduct associated with coextensive criminality.

\section{Possible ways forward}

\footnotetext{
${ }^{50}$ Apart from Conn itself, supra, n46, see also, for example, Veakins v Kier Islington Ltd [2009] EWCA Civ 1288; [2010] IRLR 132; Dowson v Chief Constable of Northumbria [2011] EWHC 2612; Levi v Bates [2015]EWCA Civ 206
} 
If it is accepted, as argued above, that workplace bullying is a phenomenon causing sufficiently adverse effects to victims, witnesses and, indeed, to employers and that it consequently requires a response, the responses currently offered by the law appear to be failing in important respects. Bullied workers have limited and often unsatisfactory avenues of redress.

One proposal mentioned above, raised at least tentatively by Hepple, is to free section 26 of the restriction it imposes of showing the harassment is causally related to a protected characteristic ${ }^{51}$. This could be described as an argument from consistency. This argument would, in essence, come down to the following - section 26 is doing good work in relation to those bullied on discriminatory grounds, but it is missing the opportunity to do other good work. If the law is committed to challenging bullying on the grounds of the protected characteristics it is hard to see why it is not equally committed to challenging bullying on other grounds as well. The victims would seem equally deserving. This is all the more so when what falls within the protected characteristics and what does not seems to have become increasingly arbitrary ${ }^{52}$. The argument from consistency is, therefore, a form of distributive argument, suggesting that like cases be treated alike.

There may be two issues with the approach of Hepple. The first is that it relies for its success on the premise that section 26 is providing an adequate response even in those circumstances where a causative connection to a protected

\footnotetext{
${ }^{51}$ Hepple, supra, n18

${ }^{52}$ English v Thomas Sanderson Blinds Ltd [2008] EWCA Civ 1421; [2009] ICR 543 in which harassment on grounds of sexual orientation was held to be made out not merely where the victim was perceived to be gay but where he was not perceived to be gay (by anyone involved) but the language used was homophobic in nature. Mr English may have been a victim of bullying deserving of redress but it is hard to see why he was any more worthy than someone bullied because his workmates did not like the clothes he wore, or the way he chose to cut his hair.
} 
characteristic is shown and, as has been argued above, that may not be the case. The second issue may seek to challenge the argument from consistency at a more fundamental level. There may be good reason why it is appropriate to have a specific and targeted cause of action where the bullying is discriminatory in nature. That reason could be the particular opprobrium that our society feels for discrimination based on certain grounds. This could certainly be made out in relation to race. As Connolly puts it 'The stigma, degradation and humiliation of slavery (and the more recent racial segregation) is revived with every modern-day act of racial discrimination ${ }^{53}$. The argument here would be that the issue is not merely one of economic disadvantage, but more widely one of historic oppression. The existence of such oppression may provide a justification for departing from notions of consistency on the basis that there are wrongs to be righted. On this approach it does not matter whether those wrongs were committed against the individuals who are now being afforded protection. Rather, group membership would operate as a transmitter of entitlement. That is, after all, the justification for certain characteristics becoming protected characteristics in the first place, when others (e.g. hair colour, handedness) do not. There is no strong evidence of high levels of historic disadvantage suffered by the fair haired or by the left-handed.

If this is true then there may be some good reasons for retaining special and targeted protection for those who suffer bullying on the basis of a protected characteristic. It recognises past historic group wrong ${ }^{54}$. Bullying more widely is not necessarily a discrimination issue. Discrimination is about historic exclusion of certain groups from access to social and economic resources. Bullying is an abuse

\footnotetext{
53 Michael Connolly, Discrimination Law (2 ${ }^{\text {nd }}$ edn, London: Sweet \& Maxwell, 2011) 3

${ }^{54}$ Aileen McColgan, Discrimination, Equality and the Law (Oxford: Hart Publishing, 2014) 67-68.
} 
of a power relationship which may be premised on discrimination but has no particular need to be ${ }^{55}$. As O'Donnell puts it, 'Bullying gets at "you”, the individual, whereas sex, race and religious discrimination targets an individual as a member of a group ${ }^{56}$. This would suggest that discrimination related bullying and bullying more generally do, in fact, represent separate mischiefs which require separate approaches.

If it is true that there is value in retaining discrimination based bullying as a special category because it reflects the notion of special opprobrium and historic disadvantage then if we were to seek to offer a remedy for bullying more generally that would need to be done through a separate cause of action. What might such a cause of action look like? This question requires a return to the issue of definition. In order to devise a workable cause of action against bullying it is necessary to decide what it is we are seeking to ban.

These are issues that have been addressed very recently in legislation in a common law jurisdiction. The Employment (Bullying at Work) Act 2014 in Gibraltar adopts the approach of enacting general anti-workplace bullying provisions while retaining intact existing law on harassment when it is 'related to an equal opportunities ground ${ }^{57}$. This legislation ('the Gibraltar Act') came into force on $18^{\text {th }}$ September 2014 and, so far, no cases under it appear to have reached the higher courts, which clearly leaves open the issue of how the judges will interpret and apply it.

\footnotetext{
${ }^{55}$ David Beale and Helge Hoel, 'Workplace bullying, industrial relations and the challenges for management in Britain and Sweden' (2010) 16 European Journal of Industrial Relations 101, 101; Peter Randall, supra, n6, 2930

${ }^{56}$ O’Donnell, supra, $\mathrm{n} 8,81$

${ }^{57}$ The equivalent to being related to a protected characteristic under Equal Opportunities Act 2006 (Gibraltar) s 14.
} 
The Gibraltar Act provides the basic right that an employer must not subject an employee to bullying ${ }^{58}$. The core definition of what constitutes bullying is found in section 4(1) which states:

'A person ("A") subjects another person ("B") to bullying where $A$ engages in conduct which has the purpose or effect of causing B to be alarmed, distressed, humiliated or intimidated'

Section 4(2) goes on to state:

'In subsection (1) the reference to conduct includes -

(a) persistent behaviour which is offensive, intimidating, abusive, malicious or insulting;

(b) persistent unjustified criticism;

(c) punishment imposed without justification;

(d) changes in the duties or responsibilities of B to B's detriment without reasonable justification',

while, subsection (3) makes clear 'bullying does not include reasonable action taken by an employer relating to the management and direction of the employee or the employee's employment'.

This definition would seem to set up a series of questions to be answered in determining whether or not a cause of action is established.

Firstly, has the employer engaged in 'conduct'? Prima facie this might be assumed to be a relatively straightforward question - has the employer done

\footnotetext{
${ }^{58}$ Employment (Bullying at Work) Act 2014 (Gibraltar) s 6(1).
} 
something ${ }^{59}$. That being the case, the clarification in subsection 2 is, arguably, both unnecessary and oddly worded. It is stated that conduct 'includes' the four matters specifically listed. This would imply that conduct is a more general concept and is not limited to those four categories. Rather the specific matters listed would seem to be things contained within the wider class while not making up the entirety of that class. This may leave open the question of whether one-off incidents can satisfy the definition. Section 4(2)(a) and (b) refer, respectively, to 'persistent' behaviour of the type specified or 'persistent unjustified criticism'. If, however, these are merely things contained within the wider class of conduct (as 'includes' would imply) but not encompassing the entire class then it seems plausible that such behaviour or criticism that is not persistent may also be 'conduct' for the purposes of subsection (1). That might raise the question of what purpose is being served by those two subclauses.

The second question within the decision procedure would seem to be this: if the employer has engaged in 'conduct' does this have 'the purpose or effect of causing [the employee] to be alarmed, distressed, humiliated or intimidated'? The conjunction 'or' ('purpose or effect') is the same wording as found in section 26 of the Equality Act 2010 and attempts to address the issue of whether or not this is a victim-oriented approach or a perpetrator-oriented approach. In reality, however, this question may set up a false dichotomy. Bullying is a function of both what the perpetrator does and what the victim perceives. An employee who perceives themselves to be bullied because they 'feel' themselves to be disliked by their manager is unlikely to satisfy the legal definition unless the manager has actually

\footnotetext{
${ }^{59}$ The Gibraltar Act makes no specific references to vicarious liability but in the absence of any statement to the contrary it is assumed that vicarious liability would apply on normal common law principles.
} 
done something to manifest that dislike. A case advanced solely on the basis that 'I can just tell he doesn't like me' is unlikely to be a case with underlying merit. Equally, a bantering culture which can appear superficially highly abusive may be a perfectly acceptable part of many a workplace culture where the relationships are marked by trust and mutual respect. Consequently, merely isolating what the perpetrator does and detaching that from who he is doing it to is likely to be problematic. Bullying is a relationship problem, a distorted interaction, and, therefore, requires that relationship to be considered as a whole. One cannot be a bully if there is no one who is being bullied. Equally, one cannot be bullied if there is no one doing the bullying.

One may question whether the formulation of 'purpose or effect' captures the need to analyse the relationship rather than looking at the matter from the perspective of either party alone. It would seem to suggest that if an employer intends to cause a defined outcome ('has the purpose... of causing') for the employee then that is sufficient to give rise to a cause of action even if the employee, in fact, feels none of those things (although, in such circumstances, the employee could, presumably, prove no loss).

It may be legitimate to ask whether the formulation 'purpose or effect' is, of itself, serving any useful purpose in the statute. If the phraseology was 'A engages in conduct which causes B to be alarmed, distressed, humiliated or intimidated' that would allow courts and tribunals to assess matters on normal causation principles, and to better analyse the nature of the relationship. While causation is, itself, an area of much controversy, the general approach is fairly well understood. 
The second element of the second question is how the prohibited environment for $\mathrm{B}$ is to be described. This legislation attempts to grapple with a significant issue in relation to efforts to frame anti-bullying legislation - the fact that all attempts to describe what is going on in bullying seem to rely on a string of adjectives of varying degrees of abstraction, in this instance 'alarmed, distressed, humiliated or intimidated'. While it is easy to object that such adjectives are imprecise and provide insufficient direction to the addressees of the law as to the allocation of rights and obligations, the reality is that the law is perfectly used to dealing with such levels of imprecision. The criminal law (which, arguably, requires a greater level of precision because of the punitive nature of its adjudications) deals well enough with similarly imprecise adjectives in, for example, section 5 of the Public Order Act 1986. What such provisions do is to set a framework within which courts and tribunals can adjudicate individual cases on their facts. There is, therefore, likely to be an inevitability that any descriptors will carry a degree of impression. What those descriptors need to do is to be indicative of the kind of relationships which are being targeted, leaving courts and tribunals to fill in the gaps. While this has some Rule of Law implications it is not unusual.

There is one further key question which appears to be treated differently by the Gibraltar Act and by section 26. This is the degree to which the assessment of liability is to be made on a subjective basis or an objective basis. Just like the question of whether the definition is victim-oriented or perpetrator-oriented, the issue of subjectivity against objectivity may also set up a false dichotomy. Both are likely to be engaged. By a subjective approach we presumably mean that the question to be asked is whether or not the victim feels himself to be a victim. This is, indeed, an approach used in the dignity at work policies of a number of (largely, public sector) 
employers. For example, the dignity at work policy of the Heart of England NHS Foundation Trust includes, at paragraph 6.1, the statement 'any individual who is accused of bullying or harassing an individual must reflect on their behaviour and ensure it does not reoccur ${ }^{60}$. This formulation seems to leave little scope for the accused to proclaim their innocence. Rather, it seems to suggest that someone who is reporting themselves to have been bullied, has been bullied. This kind of approach may work well enough in these types of policies, whose primary aim is to resolve differences through such things as mediation, conciliation and counselling, rather than to reach an adjudicated decision about the enforcement of rights. Such an approach would, however, be highly unusual in the legal system leading, potentially, to a situation in which over-reaction and the taking of excessive offence may be indulged by the courts or tribunals. By an objective approach we presumably mean that the key question is what a reasonable person in the positions of the parties might have understood to be taking place. Such an approach would bring in many of the problems that have been identified as present in section 26 , where the objective elements in the cause of action seem to have led to tribunals setting a high threshold for claimants to pass. What is required is that courts and tribunals concentrate on the relationship, requiring a consideration of both subjective and objective elements in order to take an holistic view. The Gibraltar Act offers no direction as to whether, or how far, the test is subjective or objective, allowing courts, if they take the opportunity, the chance to analyse the individual relationship in order to determine what is really going on. This clearly puts significant faith in courts and tribunals to develop the law under the Gibraltar Act in a way which leads to its being effective

\footnotetext{
${ }^{60}$ Heart of England NHS Foundation Trust - 'Dignity at Work Policy', November 2012 http://www.heartofengland.nhs.uk/wp-content/uploads/Dignity-and-Respect-at-Work-Policy-V1-Bullying-andHarassment.pdf - accessed 13th April 2017
} 
against the mischief against which it was directed. Perhaps what is required is neither a direction in the legislation as to subjectivity or objectivity but a direction to tribunals to consider all the circumstances of the case, thus empowering an holistic approach to the relationship in front of them.

The final issue in relation to an analysis of the Gibraltar Act and its approach is the question of defences. A widely drawn defence has the potential to significantly undermine the effectiveness of legislation of this type. It has already been seen that section 4(3) excludes from the definition of bullying 'reasonable action taken by an employer relating to the management and direction of the employee or the employee's employment'. It is clear that one person's reasonable and proper management can be another person's bullying ${ }^{61}$. Equally, it is clear that from time to time management will wish to pursue entirely legitimate policies which may be disliked and resented and may, therefore, be perceived as bullying. Any such provision would need to find a way to preserve the ability of employers to manage reasonably and effectively, even if that may not always be welcomed by employees. It is submitted that if legislation were to provide tribunals with an alternative direction to consider all the circumstances of the case then a specific exclusion of the sort found in section 4(3) should not be required. Whether or not the conduct was an act of legitimate and reasonable management would be one of those circumstances which tribunals could look at in their holistic consideration of the relationship.

The Gibraltar Act does, however, contain a second defence, found in section 6(5). This provides an employer with a defence provided it has in force a 'Bullying at Work Policy' which complies with certain minimum requirements set out in the

\footnotetext{
${ }^{61}$ David Van Fleet \& Ella Fleet, 'Towards a Behavioural Description of Managerial Bullying' (2012) 24 Employee Responsibilities and Rights Journal 197, 198
} 
schedule, and 'has taken all reasonable steps to implement and enforce the [policy] ${ }^{62}$ and, further, 'as soon as reasonably practicable, [the employer] takes all steps as are reasonably necessary to remedy any loss, damage or other detriment suffered by the complainant as a result of the act or acts of which he complains ${ }^{63}$.

This defence is an attempt to move the agenda beyond the question of individual rights enforceable in individual cases between employee and employer and to seek to make workplaces better places in general by rewarding employers who can say 'we have done our best' by showing that they have in place and have attempted to enforce anti-bullying policies. It can, therefore, be seen as an attempt at behaviour changing. There may be two issues with the effectiveness of this provision. Firstly, it might be questioned whether it involves a tribunal in an overly wide consideration of how the employer deals with other cases of bullying, which may be entirely unrelated to the claimant's case, with the consequent risk that the hearing becomes somewhat bloated and difficult to manage effectively. Secondly, it might be questionable whether any reward offered to an employer by the section 6 defence is likely to be sufficient to change behaviour. To get the benefit of the defence the employer needs to show not merely that it has attempted to implement its anti-bullying procedures but, also, that it has taken reasonably necessary steps to 'remedy any loss, damage or other detriment suffered by the complainant'. In reality, therefore, section 6 is saying that the employer must (effectively) have settled the claim in order to get a defence to the claim. Such a defence avoids a finding of bullying (which may be commercially valuable to the employer) but is otherwise not a defence in any real sense. While the promotion of anti-bullying policies may well be

\footnotetext{
${ }^{62} \mathrm{~S} 6(5)(\mathrm{a})(\mathrm{ii})$

${ }^{63} \mathrm{~S} 6$ 6(5)(b)
} 
seen as a good thing, it is questionable how far that should interfere with the enforcement of individual rights. After all, if an employee can prove themselves to have been the victim of bullying under the Act then, by definition, the anti-bullying policies of the employer have not been effective.

Despite its deficiencies I would submit that the Gibraltar Act, with some modifications, could offer a useful model for UK anti-bullying legislation. It provides a general remedy independent of discrimination-related harassment, thereby recognising that there are two distinct mischiefs to be dealt with. It could be improved, firstly, by giving greater emphasis to causation, and, secondly, by a direction that the tribunal consider all the circumstances of the case in order to reinforce the idea that what needs to be looked at is the nature of the relationship. The value of the section 6 defence may need to be revisited.

\section{$\underline{\text { Conclusion }}$}

This article has sought, in the first instance, to establish that workplace bullying represents an issue which merits some response from the law. While prevalence is a contested question virtually all research from the field of workplace sociology seems to show sufficient prevalence to be a problem. The varied nature of bullying also tends to mean that the consequences of the phenomenon are equally varied, but research, again in the field of workplace sociology, suggests that there are consequences for victims, witnesses and employers which are a cause of concern. As such, this article has argued that this is a problem of some moral urgency. The law should see itself as duty-bound to do what it can to assist with such a pressing problem. 
The reason bullying is of interest to workplace sociologists is because it is a social phenomenon and is, therefore, likely to need solutions that extend beyond the purely legal ${ }^{64}$. It should not be assumed that such a phenomenon will be eliminated by any individualised remedy. The law can, sometimes, deceive itself as to its omnipotence. But, it is submitted, the law can make a contribution in terms of providing remedies for individual victims. The extent to which such individualised remedies are effective in driving wider social change may sometimes be overstated, but that such legal remedies can make a contribution is part of the theory underpinning individual rights-enforcement in, for example, discrimination law generally. So, a legal remedy against bullying is unlikely to eliminate bullying. But it may be a part of a process which helps to change a culture while, at the same time, providing a remedy for individual victims who are deserving of protection.

This article has sought to demonstrate, however, that the options the law currently offers to victims of bullying are inadequate in a number of respects. That which provides the most targeted response, section 26 of the Equality Act 2010, nevertheless suffers from two very significant drawbacks - firstly that it requires a claimant to prove a causative relationship between the bullying and a protected characteristic, meaning that section 26 is receptive to some bullying but not to all. Secondly, even if such a causative relationship can be established the objective elements of the definition of the cause of action have led to a situation in which the threshold a claimant needs to cross has become high.

Section 26 offers no protection at all for those bullied for a reason which cannot be proven to be related to a protected characteristic. Such workers may be

\footnotetext{
${ }^{64}$ Anne Morris and Therese O'Donnell, 'Employment Law and Feminism' in Anne Morris \& Therese O'Donnell (eds), Feminist Perspectives on Employment Law (London: Cavendish Publishing, 1999) 11
} 
bullied for any other reason or, indeed, for no readily discernible reason at all. Such victims have no targeted protection and, instead, must rely for any remedy on other causes of action, not specifically designed for the purpose. The three most likely of these, a claim in common law negligence, a claim in 'ordinary' employment law or a claim under the Protection from Harassment Act have all been shown to have significant deficiencies. The solution proposed by Hepple, which would involve extending section 26 protection so that it was no longer limited by the need of a protected characteristic has been suggested as being undesirable because it would fail to recognise the different nature of discriminatory bullying which may, indeed, need specific protection.

Accordingly, it is proposed that a way forward may be to retain specific provision against bullying when there is a causative link to a protected characteristic but to create a separate and more general cause of action to cover other workplace bullying. This would recognise that bullying is not always a discrimination issue but, instead, is often an issue of power imbalance within a relationship. The fact that such protection may be difficult to frame is not a reason for not attempting to do so. The Gibraltar Act, while imperfect, represents a step in the right direction and may provide a basis for similar legislation in the UK. Such an approach would require a degree of partnership between legislature and judiciary in order to ensure that legislation which may contain elements of imprecision is implemented in a way consistent with its aims. While such legislation may need to leave some interpretative space for judges it is not impossible for its aims to be set out with sufficient precision.

When A.E. Housman wrote the poem 'Oh Who is that Young Sinner' his protagonist faced intolerance based upon 'the nameless and abominable colour of 
his hair'. For Housman this was a (not very) veiled reference to the legal and social status of gay people at the time ${ }^{65}$. It is not clear whether the poem influenced Joseph Losey in his 1948 film, The Boy with the Green Hair (in that instance rather more of an attack on the beginnings of McCarthyism ${ }^{66}$ ). The underlying references (to sexuality and philosophical belief) do now (at least to some level) fall within the protected characteristics and such level of protection as is afforded by section 26 . In both cases, the surface manifestations do not. Someone bullied in the workplace because of the colour of their hair finds themselves with limited and inadequate remedies. So, indeed does someone bullied because they are overweight ${ }^{67}$, or because they support the 'wrong' football team, or because their tormentor merely does not like them, or because of no discernible reason whatsoever beyond their vulnerability. Justice would seem to demand some greater element of protection for those victims.

\footnotetext{
65 In particular, the imprisonment of Oscar Wilde - Christopher Ricks, 'A.E. Housman and "the colour of his hair"' (1997) 47 Essays in Criticism 240, 240

${ }^{66}$ Colin Gardner, Joseph Losey (Manchester: Manchester University Press, 2004)

${ }^{67}$ Subject to the possibility that being sufficiently obese can satisfy the protected characteristic definition of disability, which most overweight individuals would not - Fag og Arbejde v Kommunernes Landsforning [2015] ICR 322 (CJEU)
} 